\title{
Evaluation of the factors limiting biogas production in full-scale processes and increasing the biogas production efficiency
}

\author{
Afamia I. Kouzi ${ }^{1} \cdot$ Matti Puranen $^{2} \cdot$ Merja H. Kontro ${ }^{1}$ \\ Received: 17 September 2019 / Accepted: 22 April 2020 / Published online: 15 May 2020 \\ (C) The Author(s) 2020
}

\begin{abstract}
Biogas production from sewage sludge volatile solids (VS) by anaerobic digestion slows down towards the end of the process, among inhibitory factors being $\mathrm{pH}$ increase upon ammonia accumulation, poorly digestible biomaterials, and high fixed solid (FS) content. The possibility of concentrating the digested sludge VS (41.7-56.6\% on a dry weight basis) by surface and bottom layer separation with biogas post-production was studied. Furthermore, the potential to recycle concentrated VS and digested sludge back to the process after adjusting $\mathrm{pH} 7.0$ to optimal for biogas-producing microbes and after acid, alkali, thermal, and sonolytic treatments was examined. In general, pH 7.0 control alone improved biogas production from the recycled digested sludge the most. An equally good improvement in biogas production was achieved by recycling the digested sludge, which had been heated until ammonia had evaporated and the $\mathrm{pH}$ dropped to $7.0\left(1-2 \mathrm{~h}, 75^{\circ} \mathrm{C}\right)$, and at the same time, VS was degraded. The biogas production from the sonicated and recycled sludge was almost as good as from the pH-adjusted, or heat-treated recycled sludge. After the acid and base treatments of the digested sludge, the recycled sludge yielded often the lowest biogas volume, as the added chemicals increased the FS concentration, which proved to be a more important inhibitory factor than poorly degradable VS. The high FS content significantly reduced the benefits of the treatments. By separating the surface and bottom layers with biogas post-production, the surface layer of VS was concentrated to 51.6-61.8\%, while different compositions of the layers affected the biogas production.
\end{abstract}

Keywords Digested sludge $\cdot$ Post-treatment $\cdot$ Volatile solids $\cdot$ Fixed solids $\cdot \mathrm{pH}$ changes $\cdot$ Layer separation

\begin{tabular}{ll} 
Abbreviations \\
BDS & Bottom layer of DS \\
BHSS & Bottom layer of HSS \\
BLSS & Bottom layer of LSS \\
BP & Biogas plant \\
DS & Dewatered sludge \\
E1 & Experiment 1 \\
E2 & Experiment 2 \\
FS & Fixed solids \\
HSS & High solid sludge \\
MW & Mann-Whitney test \\
\hline Responsible editor: Ta Yeong Wu \\
\hline $\begin{array}{l}\text { Merja H. Kontro } \\
\text { merja.kontro@ @elsinki.fi }\end{array}$ \\
$\begin{array}{l}\text { Faculty of Biological and Environmental Sciences, Ecosystems and } \\
\text { Environment Research Programme, University of Helsinki, }\end{array}$ \\
Niemenkatu 73, 15140 Lahti, Finland \\
Labio Ltd, Sapelikatu 7, 15160 Lahti, Finland
\end{tabular}

$\begin{array}{ll}\text { KW } & \text { Kruskal-Wallis test } \\ \text { LSS } & \text { Low solid sludge } \\ \text { PCA } & \text { Principal component analysis } \\ \text { RMA } & \text { Repeated measures ANOVA } \\ \text { SDS } & \text { Surface layer of DS } \\ \text { SHSS } & \text { Surface layer of HSS } \\ \text { SLSS } & \text { Surface layer of LSS } \\ \text { VS } & \text { Volatile solids } \\ \text { WWTP } & \text { Wastewater treatment plant }\end{array}$

\section{Introduction}

The risk of hazardous compounds limits the utilization of sewage treatment plant sludge, biogas production being one of the most common applications (Chen et al. 2008; Chen et al. 2014; Tyagi and Lo 2011). Indeed, anaerobic digestion for thermal and electrical renewable energy purposes has become a well-established technology in the wastewater effluent treatment worldwide. The microbial process converts 
wastewater sludge volatile solids (VS) into biogas; other possible substrates include manure, energy crops, and municipal solid waste (Appels et al. 2008; Gaida et al. 2017; Weiland 2010). Anaerobic biogas production is a four-stage microbial process consisting of hydrolysis, acidogenesis, acetogenesis/ dehydrogenation, and methanation, of which hydrolysis is considered to be the rate-limiting step (Nguyen et al. 2015; Weiland 2010; Feki et al. 2015; Grübel and Suschka 2015). Biogas-producing bacteria mainly belong to phyla Proteobacteria, Firmicutes, and Bacteroidetes, while the most common archaeal bacteria related to methane production belong to orders Methanomicrobiales, Methanosarcinales, Thermoplasmatales, and Methanobacteriales (Goswami et al. 2016; Han et al. 2019). The final biogas product consists mainly of methane (60-70\% in maximum) and carbon dioxide (Appels et al. 2008).

The VS concentration decreases during the anaerobic digestion due to biogas production, thereby concentrating the inhibitory or even toxic substances of the waste stream and the intermediates of microbial metabolism. The accumulation of inhibitory compounds may eventually prevent biogas production, such as inorganic ions, heavy metals, and ammonia and hydrogen that affect pH (Appels et al. 2008; Chen et al. 2008; Chen et al. 2014). Microorganisms require inorganic ions for growth, though they may affect growth rate and become toxic at high concentrations (Appels et al. 2008; Chen et al. 2008). For heavy metals, toxic concentrations have been estimated (Bååth 1989; Giller et al. 1998). Methanogens are the least tolerant for $\mathrm{pH}$ rise due to microbial degradation of proteins and urea to ammonia (Appels et al. 2008; Chen et al. 2008). The optimal $\mathrm{pH}$ range for the high solid sludge digestion is between 6.0 and 8.5 (Chen et al. 2007; Lay et al. 1997; Weiland 2010). Nevertheless, the relative importance of these various inhibitory factors in ending biogas production is not well known, although biogas production is a very common process (Zhang and Li 2019).

Biogas-producing microorganisms first consume easily available nutrients and then those that are more difficult to digest (Carrère et al. 2010; Weiland 2010). Therefore, a substantial fraction of the organic material in the final stages of biogas production is poorly microbiologically degradable, consisting of cellulose, hemicellulose, lignin, and other complex organic structures such as hair (Chen et al. 2007; Chen et al. 2008; Tyagi and Lo 2011; Weiland 2010). Enhanced digestion of poorly biodegradable organic compounds at the end of biogas production would enable VS to be recycled back into biogas production and improved recovery of organic material. Techniques that have been reported to improve the hydrolysis of difficult-to-decompose organic fractions and increase bacterial biogas production include acid or alkali treatment, thermal treatment, and sonication (Apul and Sanin 2010; Barber 2016; Carrère et al. 2010; Tyagi and Lo 2011; Zhang et al. 2010; Zhang et al. 2016; Chiu and Lo 2016).
However, the effectiveness of these different methods in improving biogas production over, for example, $\mathrm{pH}$ control alone is difficult to compare, as different VS hydrolysis techniques have rarely been compared under the same conditions with the same slurry batches. An alternative approach would be the concentrating VS to circumvent the above-presented inhibitory conditions. One such method would be flotation, in which solids are lifted to the surface by attaching to gas bubbles, followed by recovery (Rubio et al. 2002). The possibility of utilizing biogas post-production in flotation (Zeng et al. 2019) to concentrate VS for hydrolysis and recycling back to biogas production has not been studied.

Against this background, the hypothesis of the research was that surface and bottom layer separation with postproduced biogas may concentrate VS and, after digestion, they can be recycled to increase biogas production. Furthermore, it was hypothesized that VS transformation to biogas can be improved by the following post-treatments: $\mathrm{pH}$ adjustment, and digesting difficult-to-decompose organic fractions, combined with recycling back into the process. The VS digestion methods used were acid/alkali, thermal, and sonolytic treatments.

\section{Materials and methods}

\section{Samples and chemical analyses}

Low solid sludge (LSS) and dewatered sludge (DS) were collected in Lahti Aqua Ltd. wastewater treatment plant (WWTP, Lahti, Finland), and high solid sludge (HSS) was collected in Labio Ltd. biogas plant (BP, Lahti, Finland), all immediately after biogas production. WWTP produced biogas in low solid process and BP in high solid biogas production process. The sewage sludge was used as a raw material in both processes, and BP mixed the source-separated biowaste with the sewage sludge in a ratio of about $3: 1$. For experiment 1 (E1), the LSS was aerated after biogas production, but not for experiment 2 (E2). Aeration reduces microbial biogas-producing activity. Samples for E1 were collected on November 29, 2017, and those for E2 on February 7, 2018. On the sampling day, the sludges were weighed for total (TS), fixed (FS), and volatile (VS) solid analyses; for $\mathrm{pH}$ measurements; element analyses, surface, and bottom layer separations; and for measuring timedependent changes in sludge $\mathrm{pH}$ (experiment 3, E3). Then, the sludges were frozen at $-20{ }^{\circ} \mathrm{C}$ for biogas production experiments.

TS (heating for $20 \mathrm{~h}$ at $105^{\circ} \mathrm{C}$ ), FS, and VS (heat treatment for $4 \mathrm{~h}$ at $550^{\circ} \mathrm{C}$ ) of the sludges were determined in triplicate as presented earlier (Kerminen et al. 2018). To measure pH, $1.0 \mathrm{~g}$ of sludge was mixed with $4 \mathrm{~mL}$ of distilled water, and the mixture was shaken for $1 \mathrm{~h}$ at $150 \mathrm{rpm}$ (Laboshake; Gerhardt, 
Königswinter, Germany). Then, the liquid was separated by centrifugation at $2027 \mathrm{rpm}$ (Heraeus 1S-R with 75002002 rotor, DJB Labcare, Buckinghamshire, UK; $3000 \times g$, $10 \mathrm{~min}$ ), and $\mathrm{pH}$ was measured using InoLab series $\mathrm{pH}$ $720 \mathrm{~m}$ (Weilheim, Germany) (Kurola et al. 2011). Alternatively, $\mathrm{pH}$ was measured using the $\mathrm{pH}$ paper (Fisher Scientific, Hampton, NH, USA). Carbon and nitrogen were determined using LECO CNS-2000 elemental analyzer (LECO Corporation, St. Joseph, MI, USA) as presented previously (Talja et al. 2008). To measure the elements $\mathrm{Al}, \mathrm{Co}$, $\mathrm{Cr}, \mathrm{Cu}, \mathrm{Mn}, \mathrm{Ni}, \mathrm{Fe}, \mathrm{Zn}, \mathrm{P}, \mathrm{V}$, and $\mathrm{Pb}$, the sludge was treated with nitric acid in a MARS 6 microwave digestion system according to the manufactures instructions (CEM Corporation, Matthews, NC, USA). Then, the samples were diluted with water to a nitric acid concentration of $2 \%$ (vol/ vol), and the elements were measured using the Sciex Elan 6000 ICP-MS equipment (Perkin Elmer Inc., Waltham, MA, USA). The method is based on standards (SFS-ISO 17294-1 2004; SFS-EN ISO 17294-2 2016).

\section{Surface and bottom layer separation}

For E1, to separate surface and bottom layers by biogas postproduction, 2.0 L of LSS (wet weight (wt) $2010 \mathrm{~g}$; TS, $51 \mathrm{~g}$ ) was transferred to a $6-\mathrm{L}$ plastic container. A $1.0-\mathrm{L}$ volume of DS (wet wt, $600 \mathrm{~g}$; TS, $159 \mathrm{~g}$ ) and HSS (wet wt, $885 \mathrm{~g}$; TS, $175 \mathrm{~g}$ ) was mixed with $1.5 \mathrm{~L}$ of distilled water in 6-L plastic containers. The sludges in triplicate were incubated at the room temperature of 21 $\pm 2{ }^{\circ} \mathrm{C}$ for 40 days. The surface layers were collected, water was separated by centrifugation at $2027 \mathrm{rpm}$ $(3000 \times g, 10 \mathrm{~min})$, and the sludges were frozen at $20{ }^{\circ} \mathrm{C}$ for the biogas production experiment.

For E2, to separate surface and bottom layers, $2.0 \mathrm{~L}$ of LSS (wet wt, $1930 \mathrm{~g}$; TS, $70 \mathrm{~g}$ ) was transferred to a 3-L plastic container. DS (wet wt, $600 \mathrm{~g}$; TS, $161 \mathrm{~g}$ ) and HSS (wet wt, $885 \mathrm{~g}$; TS, $208 \mathrm{~g}$ ) of $1.0 \mathrm{~L}$ were mixed with $1.5 \mathrm{~L}$ of distilled water and incubated in 3-L plastic containers, all at the room temperature of $21 \pm 2{ }^{\circ} \mathrm{C}$ in triplicate. The surface and bottom layers were collected after 28 (HSS, surface layer $7.4 \mathrm{~g}$ dry wt, bottom layer $281 \mathrm{~g}$ dry wt) and 33 days (LSS, surface layer $10.3 \mathrm{~g}$ dry $\mathrm{wt}$; bottom layer $89.6 \mathrm{~g}$ dry wt; DS surface layer, 32.9 g dry wt; bottom layer, $320 \mathrm{~g}$ dry wt); water was removed by centrifugation at $2027 \mathrm{rpm}(3000 \times \mathrm{g}, 10 \mathrm{~min})$, and the sludges were frozen at $20{ }^{\circ} \mathrm{C}$ for the biogas production experiment. To follow the surface and bottom layer separation, another set of similar incubations in triplicate was done from DS and HSS, and the samples were collected from bottom and surface layers after $5,12,19,26$, and 28 days.

\section{Biogas production}

All biogas measurements were done in triplicate, and biogas yield was calculated as $\mathrm{mL}$ of biogas/g of VS on a dry weight basis. In E1, to measure biogas production, the methaneproducing microbial community of the WWTP was transferred to $20-\mathrm{mL}$ syringes in $10 \mathrm{~mL}$ of LSS, with and without pH 7.0 adjustments. Then acid- or alkali-treated and acid- or alkali-neutralized sludges were recycled to the LSS with $\mathrm{pH}$ 7.0. The LSS properties were as follows: $\mathrm{pH}, 9.0$; TS, $2.5 \pm$ $0.1 \%$; VS, $45.6 \pm 0.1 \%$ of TS; FS, $54.4 \pm 0.1 \%$ of TS. The quantities of TS, VS, and FS in the sludges of E1 and the VS substrate to inoculum ratios ( $S / I$ ratios) are presented in Table 1. The average of VS $S / I$ ratios was $0.76 \pm 0.31$ in E1, and the ratio ranged between 0.41 and 1.24; i.e., changes in the ratios may have had minor effects on biogas production, which has been the best close to $S / I$ ratio of 1:1 (Córdoba et al. 2018). Biogas production was monitored from the increase in gas volume in an airtight syringe with a flexible piston for 24 days at $37^{\circ} \mathrm{C}$ (model $\mathrm{C} 25 \mathrm{KC}$ incubator shaker, New Brunswick Scientific Co., Edison, NJ. USA). In E2, to measure biogas production, the WWTP methane-producing microbial community was transferred to a $20-50-\mathrm{mL}$ syringe in $5 \mathrm{~mL}$ of LSS, with and without $\mathrm{pH} 7.0$ adjustment. The treated sludges (acid/alkali treatment, thermal treatment, sonication) were recycled to the LSS with $\mathrm{pH}$ 7.0. The LSS properties were as follows: $\mathrm{pH}, 7.9$; TS, $3.7 \pm 0.1 \%$; VS, $54.6 \pm 9.1 \%$ of TS; FS, $45.4 \pm 9.1 \%$ of TS. The quantities of TS, VS, and FS in the sludges of E2, and the VS $S / I$ ratios are presented in Table 1. The average VS $S / I$ ratios were $1.52 \pm 0.89$ in E2, and the ratio ranged between 0.54 and 2.90 . Biogas production at $37^{\circ} \mathrm{C}$ and under $30 \mathrm{rpm}$ shaking was followed for 14 days.

\section{Digested sludge post-treatments to improve biogas production}

All experiments were done in triplicate. TS, VS, FS, and wet weights of sludges in the treatments were as presented in Table 1. In E1, the LSS volume was $10 \mathrm{~mL}$ (digested sludge collected after aeration) in biogas production experiments, and the sludge treatments in the first experiment were $\mathrm{pH} 7.0$ adjustment and acid and alkali hydrolysis. In E2, the LSS volume was $5 \mathrm{~mL}$ (digested sludge collected prior to aeration) in biogas production experiments, and the treatments were as follows: $\mathrm{pH} 7.0$ adjustment; acid and alkali hydrolysis; thermal treatment; and sonication.

\section{$\mathrm{pH}$ adjustment}

In E1, the initial $\mathrm{pH}$ values of the LSS, DS, and HSS were 9.0, 8.0 , and 10.0, respectively. Biogas production in the sludges (LSS bacterial inoculum $10 \mathrm{~mL}$ ) was measured with and without $\mathrm{pH} 7.0$ adjustment. In E2, the initial $\mathrm{pH}$ values of the LSS, 
Table 1 Total solid (TS), volatile solid (VS), and fixed solid (FS) concentrations; wet weights; and/or substrate to inoculum VS ratios (S/I ratio) of sludges in treatments, and in biogas production experiments. Values are presented as average \pm S.D $(n=3)$

\begin{tabular}{|c|c|c|c|c|}
\hline Sludges in treatments & Wet weight & TS (g dry weight) & VS (g dry weight) & FS (g dry weight) \\
\hline \multicolumn{5}{|l|}{ Experiment $1(\mathrm{E} 1)$} \\
\hline Low solid sludge (LSS) & $10 \mathrm{~mL}$ & $0.251 \pm 0.009$ & $0.115 \pm 0.004$ & $0.136 \pm 0.005$ \\
\hline Surface layer of LSS (SLSS) & $1.0 \mathrm{~g}$ & $0.092 \pm 0.004$ & $0.047 \pm 0.001$ & $0.045 \pm 0.003$ \\
\hline Dewatered sludge (DS) & $1.0 \mathrm{~g}$ & $0.263 \pm 0.001$ & $0.142 \pm 0.001$ & $0.121 \pm 0.001$ \\
\hline Surface layer of DS (SDS) & $1.0 \mathrm{~g}$ & $0.143 \pm 0.007$ & $0.076 \pm 0.004$ & $0.067 \pm 0.003$ \\
\hline High solid sludge (HSS) & $1.0 \mathrm{~g}$ & $0.197 \pm 0.003$ & $0.091 \pm 0.001$ & $0.106 \pm 0.003$ \\
\hline Surface layer of HSS (SHSS) & $1.0 \mathrm{~g}$ & $0.151 \pm 0.061$ & $0.071 \pm 0.013$ & $0.080 \pm 0.072$ \\
\hline \multicolumn{5}{|l|}{ Experiment 2 (E2) } \\
\hline Low solid sludge (LSS) & 5.183 & $0.183 \pm 0.002$ & $0.099 \pm 0.016$ & $0.083 \pm 0.017$ \\
\hline Surface layer of LSS (SLSS) & 1.305 & 0.100 & $0.053 \pm 0.001$ & $0.047 \pm 0.001$ \\
\hline Bottom layer of LSS (BLSS) & 1.044 & 0.100 & $0.053 \pm 0.001$ & $0.047 \pm 0.001$ \\
\hline Dewatered sludge (DS) & 1.869 & 0.500 & $0.283 \pm 0.002$ & $0.217 \pm 0.002$ \\
\hline Surface layer of DS (SDS) & 1.616 & 0.200 & $0.111 \pm 0.002$ & $0.089 \pm 0.002$ \\
\hline Bottom layer of DS (BDS) & 1.570 & 0.200 & $0.111 \pm 0.001$ & $0.089 \pm 0.001$ \\
\hline High solid sludge (HSS) & 2.125 & 0.500 & $0.208 \pm 0.008$ & $0.292 \pm 0.008$ \\
\hline Surface layer of HSS (SHSS) & 1.463 & 0.200 & $0.103 \pm 0.013$ & $0.097 \pm 0.013$ \\
\hline Bottom layer of HSS (BHSS) & 1.412 & 0.200 & $0.163 \pm 0.048$ & $0.337 \pm 0.048$ \\
\hline Sludges in biogas production experiments & $\mathrm{S} / \mathrm{I}$ ratio & TS (g dry weight) & VS (g dry weight) & FS (g dry weight) \\
\hline \multicolumn{5}{|l|}{ Experiment $1(\mathrm{E} 1)$} \\
\hline Low solid sludge (LSS) & & $0.251 \pm 0.009$ & $0.115 \pm 0.004$ & $0.136 \pm 0.005$ \\
\hline Surface layer of LSS (SLSS) & $0.41 \pm 0.01$ & $0.343 \pm 0.011$ & $0.162 \pm 0.005$ & $0.181 \pm 0.006$ \\
\hline Dewatered sludge (DS) & $1.24 \pm 0.04$ & $0.514 \pm 0.009$ & $0.257 \pm 0.004$ & $0.257 \pm 0.005$ \\
\hline Surface layer of DS (SDS) & $0.66 \pm 0.03$ & $0.394 \pm 0.014$ & $0.190 \pm 0.007$ & $0.204 \pm 0.007$ \\
\hline High solid sludge (HSS) & $0.79 \pm 0.03$ & $0.448 \pm 0.010$ & $0.206 \pm 0.003$ & $0.242 \pm 0.007$ \\
\hline Surface layer of HSS (SHSS) & $0.62 \pm 0.13$ & $0.402 \pm 0.070$ & $0.186 \pm 0.011$ & $0.216 \pm 0.076$ \\
\hline \multicolumn{5}{|l|}{ Experiment $2(\mathrm{E} 2)$} \\
\hline Low solid sludge (LSS) & & $0.183 \pm 0.002$ & $0.100 \pm 0.016$ & $0.083 \pm 0.017$ \\
\hline Surface layer of LSS (SLSS) & $0.54 \pm 0.08$ & $0.282 \pm 0.002$ & $0.152 \pm 0.017$ & $0.130 \pm 0.017$ \\
\hline Bottom layer of LSS (BLSS) & $0.54 \pm 0.09$ & $0.283 \pm 0.002$ & $0.152 \pm 0.016$ & $0.131 \pm 0.017$ \\
\hline Dewatered sludge (DS) & $2.90 \pm 0.46$ & $0.683 \pm 0.002$ & $0.383 \pm 0.018$ & $0.300 \pm 0.019$ \\
\hline Surface layer of DS (SDS) & $1.14 \pm 0.20$ & $0.383 \pm 0.002$ & $0.211 \pm 0.015$ & $0.172 \pm 0.015$ \\
\hline Bottom layer of DS (BDS) & $1.14 \pm 0.19$ & $0.383 \pm 0.002$ & $0.211 \pm 0.016$ & $0.172 \pm 0.017$ \\
\hline High solid sludge (HSS) & $2.13 \pm 0.34$ & $0.683 \pm 0.002$ & $0.308 \pm 0.019$ & $0.375 \pm 0.020$ \\
\hline Surface layer of HSS (SHSS) & $1.04 \pm 0.04$ & $0.383 \pm 0.002$ & $0.203 \pm 0.029$ & $0.180 \pm 0.030$ \\
\hline Bottom layer of HSS (BHSS) & $1.72 \pm 0.74$ & $0.683 \pm 0.002$ & $0.263 \pm 0.032$ & $0.420 \pm 0.032$ \\
\hline
\end{tabular}

SLSS, BLSS, DS, SDS, BDS, HSS, and SHSS, and BHSS was $7.9,8.7,8.7,8.8,7.4,7.4,8.5,8.3$, and 8.3 , respectively. Biogas production in the sludges (LSS bacterial inoculum $5 \mathrm{~mL}$ ) was measured with and without $\mathrm{pH} 7.0$ adjustment. In $\mathrm{E} 1$ and $\mathrm{E} 2$, the $\mathrm{pH} 7.0$ was adjusted with $37 \%$ hydrochloric acid $(\mathrm{HCl})$, and $\mathrm{pH}$ was measured using $\mathrm{pH}$ paper. In $\mathrm{E} 3$, to monitor whether the sludge $\mathrm{pH}$ could be lowered to 7.0 during storage at the room temperature of $21 \pm 2{ }^{\circ} \mathrm{C}$ without acid addition, DS (dry wt $26.8 \mathrm{~g}$ ) and HSS (dry wt $23.5 \mathrm{~g}$ ) with the wet wt of $100 \mathrm{~g}$ were transferred in a 0.5 -L decanter class covered with an aluminum foil. The samples of $1.0 \mathrm{~g}$ were taken after $0,1,2,5,6,12,32$, and 35 days for the $\mathrm{pH}$ measurement. The $\mathrm{pH}$ was measured using InoLab series $\mathrm{pH} 720 \mathrm{~m}$ as presented above.

\section{Acid and alkaline hydrolysis}

To study the effects of acid hydrolysis of digested sludge on biogas production, the $\mathrm{pH}$ value of sludge was adjusted to $\mathrm{pH}$ $1.0,2.0$ or 3.0 using $37 \% \mathrm{HCl}$, and the solutions were incubated at the room temperature of $21 \pm 2{ }^{\circ} \mathrm{C}$ for $24 \mathrm{~h}$ (Devlin et al. 2011). To study the effects of alkaline hydrolysis of 
digested sludge on biogas production, the $\mathrm{pH}$ values of sludges were adjusted to $\mathrm{pH} 10.0$ or 12.0 using $10 \mathrm{M}$ potassium hydroxide $(\mathrm{KOH})$, and the solution was incubated at the room temperature of $21 \pm 2{ }^{\circ} \mathrm{C}$ for $48 \mathrm{~h}$ (Rafique et al. 2010). After the treatments, the samples were neutralized; i.e., $\mathrm{pH} 7.0$ was adjusted using $\mathrm{HCl}$ or $\mathrm{KOH}$.

In E1, the acid-treated (pH 1.0, 2.0, and 3.0) or alkalinetreated $(\mathrm{pH} 10.0$, and 12.0) sludges were recycled to biogas production; i.e., the sludges were amended in $10 \mathrm{~mL}$ of LSS to measure biogas production. The acid- or alkaline-treated sludge samples were SLSS (pH 1.0 and 12.0), DS (pH 1.0 and 12.0), SDS ( $\mathrm{pH} 1.0,2.0,3.0,10.0$ and 12.0), HSS (pH 1.0 and 12.0), and SHSS (pH 1.0 and 12.0). In E2, the acid-treated $(\mathrm{pH} 3.0)$ or alkaline-treated $(\mathrm{pH}$ 10.0) sludges were recycled to biogas production; i.e., the sludges were amended in $5 \mathrm{~mL}$ of LSS to measure biogas production. The acid- or alkaline-treated sludge samples were SLSS ( $\mathrm{pH} 10.0$ ), and BLSS (pH 10.0), DS (pH 3.0 or 10.0), SDS (pH 10.0), BDS (pH 10.0), HSS (pH 3.0 and 10.0), SHSS (pH 10.0), and BHSS (pH 10.0).

\section{Thermal treatment (heating) and sonication}

In E2, to disrupt the sludge microbial cells and VS, and to change sludge rheology, the sludges were heated in a water path (Grant SUB 14, Cambridge, UK) at $75^{\circ} \mathrm{C}$ until the $\mathrm{pH}$ fell to 7.0 due to ammonia evaporation (Barber 2016; Bonmatí and Flotats 2003; Climent et al. 2007; Tyagi and Lo 2011). The incubation time varied between 1 and $3 \mathrm{~h}$. The heattreated sludges were amended in $5 \mathrm{~mL}$ of LSS to measure biogas production. The heat-treated sludges were SLSS $(3 \mathrm{~h})$, BLSS $(3 \mathrm{~h})$, DS $(3 \mathrm{~h})$, SDS $(2 \mathrm{~h})$, BDS $(2 \mathrm{~h})$, HSS $(2 \mathrm{~h})$, SHSS ( $1 \mathrm{~h})$, and BHSS (1 h).

The high pressure created by sonication causes microbubble formation, which collides and releases energy for radical formation and biological material disruption (Apul and Sanin 2010). For sonolytic treatment, the sludges were sonicated for $60 \mathrm{~min}$ at $43 \mathrm{kHz}$ and $320 \mathrm{~W}$ (Branson 8510 Ultrasonic, Danbury, USA) until the $\mathrm{pH}$ fell to 7.0. The sonicated sludges were amended in $5 \mathrm{~mL}$ of LSS and biogas production was measured. The sonicated sludges were DS and HSS.

\section{Calculations}

The results were calculated as an average \pm standard deviation (S.D.) $(n=3)$. Statistical analyses were performed using IBM SPSS Statistics 24 (New York, USA). The repeated measures ANOVA (RMA) followed by pairwise comparisons (PC) was used to determine whether the VS concentration differed between the surface and bottom layers of DS and HSS and whether the sludge $\mathrm{pH}$ changed during storage. The principal component analysis (PCA) was used to elucidate the distribution of inorganic ions into the surface and bottom layers of DS and HSS. Two-factor (sludge, treatment) Kruskal-Wallis (KW) test followed by Mann-Whitney's test (MW) was used to determine whether sludge compositions and treatments had an effect on biogas yield.

\section{Results and discussion}

The LSS total solid content of $3.1 \pm 0.6 \%$ of wet wt was low at the end of WWTP biogas production process. It was increased by centrifugation to $26.6 \pm 0.31 \%$ of the DS, while the total solid content of the BP HSS was $21.6 \pm 2.2 \%$ after biogas production. The percentages of VS in the LSS (E1, 45.6 \pm $0.1 \%$ of dry wt; E2, $54.6 \pm 9.1 \%)$, DS (E1, $54.1 \pm 0.1 \%$; E2, $56.6 \pm 0.4 \%$ ), and HSS (E1, $46.3 \pm 0.8 \%$; E2, $41.7 \pm 1.7 \%$ ) were still quite high at the end of biogas production. The $\mathrm{pH}$ values of the LSS (E1 9.0/E2 7.9), DS (E1 8.0/E2 8.8), and HSS (E1 10.0/E2 8.5) were close to the upper limit of biogasproducing bacteria (about $\mathrm{pH} 8.5$ ) or higher, most likely due to ammonia release from proteins and urea (Appels et al. 2008; Chen et al. 2007; Lay et al. 1997; Weiland 2010) (Table 2).

As the factors like high element/FS concentration, high $\mathrm{pH}$, and difficult-to-digest VS composition are suggested to limit biogas production (Appels et al. 2008; Chen et al. 2008), the importance of these factors in reducing biogas yields to below profitable levels at VS concentrations as high as 41.7-56.6\% was evaluated. Furthermore, the possibility to concentrate the VS of the LSS, DS, and HSS by lifting onto the surface with biogas post-production and to digest them into more suitable substrates for biogas-producing bacteria was studied.

\section{Surface and bottom layer separation}

The feasibility of concentrating VS by raising to the surface using biogas post-production was studied, as gases are known to carry suspended matter on the water surface (Rubio et al. 2002). In E1, the initial VS concentration of $46.3 \pm 0.8 \%$ for HSS increased to $61.8 \pm 3.6 \%$ in the surface layer and decreased to $42.9 \pm 7.3 \%$ in the bottom layer, the difference being $18.9 \%$ in 40 days. Then, in E2, the changes in the VS concentration were followed during the incubation (Fig. 1a). The VS concentration in the surface layer of HSS increased significantly from $41.7 \pm 1.7 \%$ to $51.6 \pm 6.6 \%$ in 28 days, while the bottom layer VS concentration decreased to 32.7 $\pm 9.6 \%$ (RMA-PC, $p=0.001$ ). The greatest difference in VS concentration between the surface and bottom layers was achieved in 19 days, and it was again as much as $18.9 \%$ on a dry weight basis. Based on total C, 60.1\% (236.5 \pm $11.2 \mathrm{~g} / \mathrm{kg}$ ) of total C was accumulated on the surface of HSS and $39.9 \%(157.3 \pm 9.0)$ on the bottom, the difference of $20.1 \%$ being close to that calculated on the basis of VS (Table 2). In contrast to HSS, the VS concentration for DS 


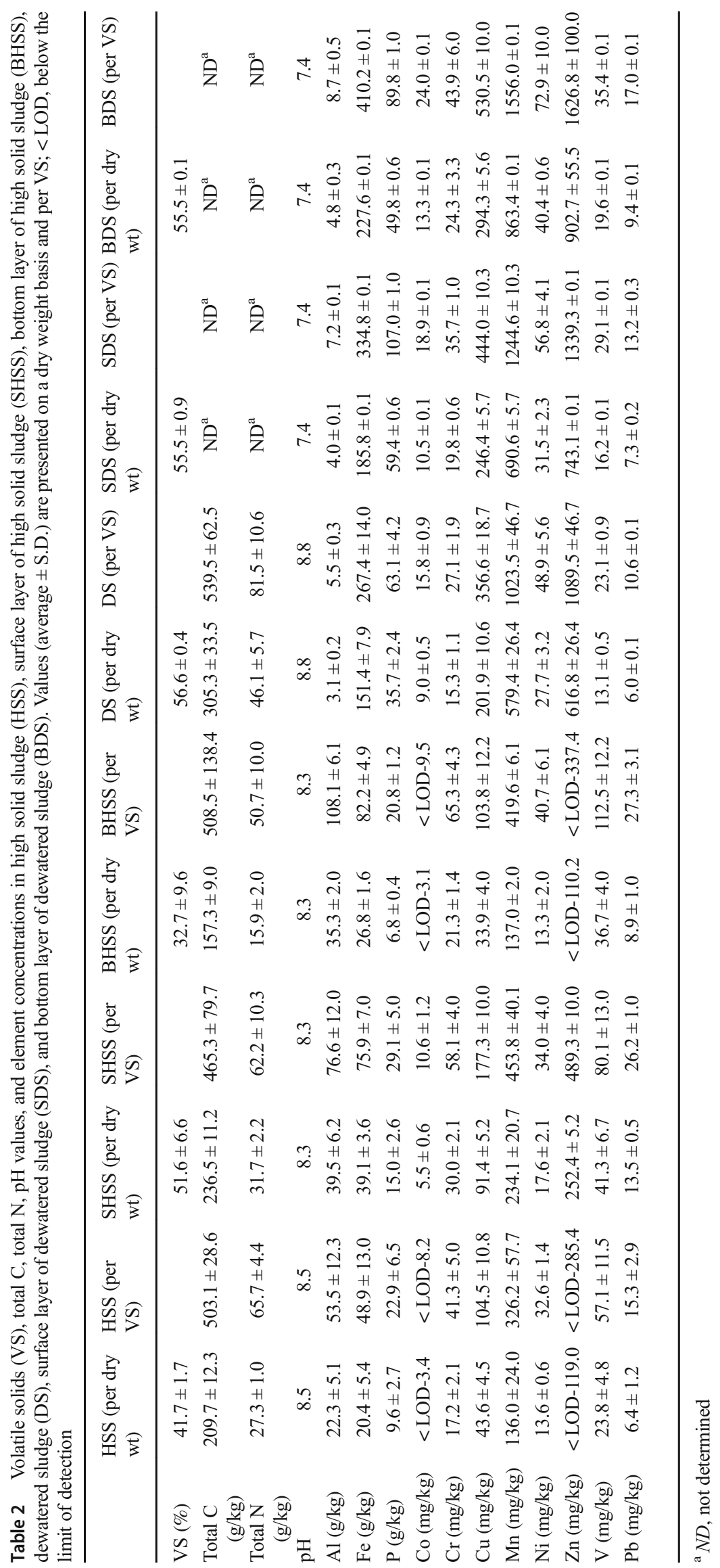




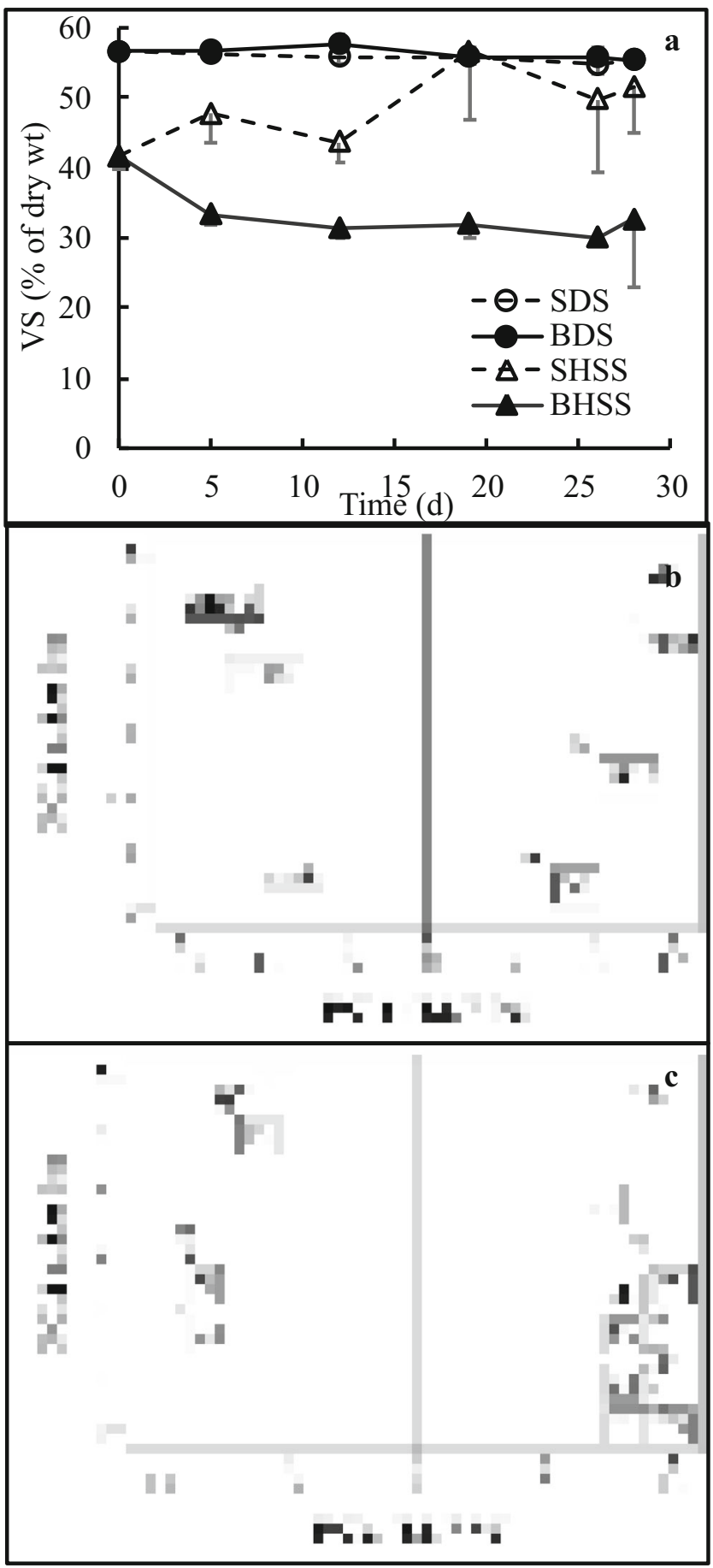

Fig. 1 a Volatile solid (VS) content in the dewatered sludge (DS) surface (SDS) and bottom (BDS) layers, and in the high solid sludge (HSS) surface (SHSS) and bottom (BHSS) layers, separated by biogas postproduction $(n=3$; the average of standard deviations, $2.2 \%)$. b Principal component analysis score plot showing the separation of DS, SDS, BDS, HSS, SHSS, and BHSS along the PC1 and PC2 axes based on the elemental compositions. $\mathbf{c}$ Loading values for elements along the PC1 and PC2 axes

did not differ between the surface and bottom layers (E1: initial $54.1 \pm 0.1 \%$, end $54.0 \pm 1.4 \%$; E2: initial $56.6 \pm 0.4 \%$, end $55.5 \pm 0.9 \%$, RMA-PC, $p=0.161)$. Similarly, the VS concentration for LSS did not differ between the surface and bottom layers (E2: initial $52.9 \pm 0.6 \%$, end $52.5 \pm 0.5 \%$ ). Thus, the highest percentage of VS that could be accumulated on the surface layer varied between 51.6 and $61.8 \%$ of dry weight (Fig. 1a; Table 2).

The quantity of sludge brought to the surface by biogas post-production was low, only about $2.6 \%$ of HSS, and $10.3 \%$ of DS based on the dry weight. However, all large solids were removed from the surface before weighting, which leads to an underestimation of the separation efficiency especially in HSS, which contained source-separated biowaste with plastic bag residues. Elemental concentrations in the surface and bottom layers of HSS and DS were usually equal to or higher than in the sludges prior to separation the layers, which indicates that part of the VS may have been lost during the layer separation process as volatile biogas, or as dissolved in the liquid phase due to water addition (Table 2).

The major differences in the elemental compositions per VS were due to differences between HSS and DS, covering $82.7 \%$ of variance in the PCA (Fig. 1b). The concentrations of $\mathrm{Fe}, \mathrm{P}, \mathrm{Co}, \mathrm{Cu}, \mathrm{Mn}, \mathrm{Ni}$, and $\mathrm{Zn}$ in DS were higher than in HSS, while those of $\mathrm{Al}$ and $\mathrm{V}$ were highest in HSS (Fig. 1c and Table 2). $\mathrm{Cr}$ and $\mathrm{Pb}$ concentrations did not differ much between HSS and DS. Differences in elements between sludges, surface layers, and bottom layers accounted for $15.0 \%$ of variance along the PCA PC2 axis (Fig. 1b, c). Elemental concentrations per VS had a tendency to increase in the following order: Sludge $<$ surface $<$ bottom (Table 2). Their concentrations were among the highest in the DS bottom layer, where the VS content was almost the same at the surface and bottom. However, the $\mathrm{P}, \mathrm{Cu}, \mathrm{Mn}$, and $\mathrm{Zn}$ concentrations were highest in the surface layer of HSS (VS, 51.6\%), which had much more VS to adsorb elements than the bottom layer (VS, $32.7 \%$ ).

Although elemental concentrations were affected by surface and bottom layer separation, still quite high concentrations were found in both layers. Especially $\mathrm{Cu}$ and $\mathrm{Zn}$ concentrations were high enough to inhibit microbial activity in all sludges (Bååth 1989), and increasing elemental concentrations generally increase osmotic pressure. The surface and bottom layer separation was not very efficient in concentrating the elements, but it may be possible to use to increase the surface layer VS concentration relative to the bottom. Factors that are known to affect the surface and bottom layer separation include the efficiency of methane post-production, water quantity, substances dissolved in water, sludge composition, and $\mathrm{pH}$ (Rubio et al. 2002). For example, $\mathrm{Cr}, \mathrm{Cu}, \mathrm{Ni}$, and $\mathrm{Zn}$ are released from the sludge into the liquid at low $\mathrm{pH}$ values below 6.3 (Adams and Sanders 1984; Wong et al. 2002). The optimization of these conditions could improve the separation efficiency. In addition, surface and bottom layer separation immediately at the end of biogas production process could be more efficient, and the biogas produced during 
surface separation could be recovered. The activity of the biogas-producing microbial community would not be affected by aeration as a post-treatment, transportation, and storage under aerobic conditions for up to $24 \mathrm{~h}$ prior to the start of experiments, and freezing, as was in this study.

\section{Digested sludge post-treatments to improve biogas production}

To improve biogas production from recycled digestate, the $\mathrm{pH}$ of the digestate was adjusted to 7.0, which is optimal for methane-producing bacteria (Appels et al. 2008; Chen et al. 2008). In addition, sludge VS were hydrolyzed by acid, alkali, heat, or sonolytic treatment, followed by recycling to biogas production. Based on statistical analysis using $\mathrm{KW}$, the treatments $(p<0.001)$ and recycled materials $(p<0.050)$ affected especially biogas production, as shown below.

\section{Digested sludge $\mathrm{pH}$ adjustment}

In E1 and E2, the pH of the LSS, DS, and HSS, and their surface and bottom layers was adjusted to $\mathrm{pH} 7.0$ from the $\mathrm{pH}$ values of 7.4-10.0, and then the sludges were recycled to biogas production. Biogas production was compared with that in the same recycled sludge without adjusted pH (Figs. 2 and 3 , black bars). Generally, the recycling of non-pH-adjusted sludges to biogas production increased biogas yield compared with LSS without $\mathrm{pH}$ adjustment, except not the SLSS (Fig. 3a) and BHSS (Fig. 3c) recycling. Similarly, according to Yadvika et al. (2004), the sole recirculation of sludge back to biogas production has increased biogas yield, but only marginally. Biogas yield was further increased, when the $\mathrm{pH}$ of the sludges was adjusted to 7.0 (MW, $p<0.001$; Figs. 2 and 3, black bars). Indeed, adjusting the $\mathrm{pH}$ of the microwave $\mathrm{H}_{2} \mathrm{O}_{2}$ pre-treated sludge also improved biogas production (Eswari et al. 2016). Thus, ammonia release from proteins and urea appeared to raise the $\mathrm{pH}$ of sludges above the optimum of biogas production (Appels et al. 2008; Chen et al. 2008). Adjusting the $\mathrm{pH}$ of the recycled digested sludge was one of the most effective methods for achieving a high biogas yield.

In E3, the $\mathrm{pH}$ of DS and HSS was monitored for 35 days to determine if it could be lowered to $\mathrm{pH} 7.0$ during storage without the addition of acid or base. The water evaporated during incubation, as dry weight increased from 26.8 to $48.2 \%$ in DS (RMA-PC, $p=0.002$ ) and from $23.5 \pm 0.8$ to $77.1 \pm 17.7 \%$ in HSS (RMA-PC, $p=0.002$ ). At the same time, the $\mathrm{pH}$ of the coarse and aerobic DS decreased from the initial $\mathrm{pH} 8.8$ to $\mathrm{pH} 6.8-7.2$ in 5-6 days, and further to 5.3 in 35 days (RMA-PC; $p<0.001$ ) (Fig. 4). For comparison, in the surface and bottom layer separation, the $\mathrm{pH}$ of DS with added water only decreased from 8.8 to 7.4 during 33 days of incubation under saturated conditions (Fig. 1, Table 2). During DS storage in $\mathrm{E} 3$, the decrease in $\mathrm{pH}$ was associated with only a $2.9 \%$ decrease in total $\mathrm{N}$, from $46.1 \pm 5.7$ to $44.9 \pm 1.2 \mathrm{~g} / \mathrm{kg}$ (RMAPC, $p=0.003$ ) (Fig. 4). Total $\mathrm{C}$ decreased more in E3, 29.8\% from $305.3 \pm 33.5$ to $214.3 \pm 12.0 \mathrm{~g} / \mathrm{kg}$ (RMA-PC, $p<0.001$ ), while the VS percentage remained almost the same (57.1 \pm $0.6 \%$ of dry wt) for 35 days. Ammonia released from proteins and urea appeared to be microbiologically bound to biomass in coarse and aerobic DS, as only little nitrogen was lost even though the $\mathrm{pH}$ decreased. Simultaneously some carbon was lost in cellular respiration.

In $\mathrm{E} 3$, the $\mathrm{pH}$ changes in HSS differed from those in DS. The $\mathrm{pH}$ of HSS increased from an initial $\mathrm{pH}$ of 8.5 to 8.9 during a 35-day incubation (RMA-PC, $p<0.001$ ), while total $\mathrm{N}$ decreased by $61.9 \%$ from $27.3 \pm 1.0 \mathrm{~g} / \mathrm{kg}$ to $10.4 \pm 0.7 \mathrm{~g} / \mathrm{kg}$ (RMA-PC, $p=0.003$ ). Total $\mathrm{C}$ decreased as much as $64.5 \%$, from $209.7 \pm 12.3 \mathrm{~g} / \mathrm{kg}$ to $74.4 \pm 5.4 \mathrm{~g} / \mathrm{kg}$ (RMA-PC, $p \leq$ 0.001 ), though these changes were not clearly seen in the VS content (initial $41.7 \pm 1.7 \%$; final $48.6 \pm 15.7 \%$ of dry

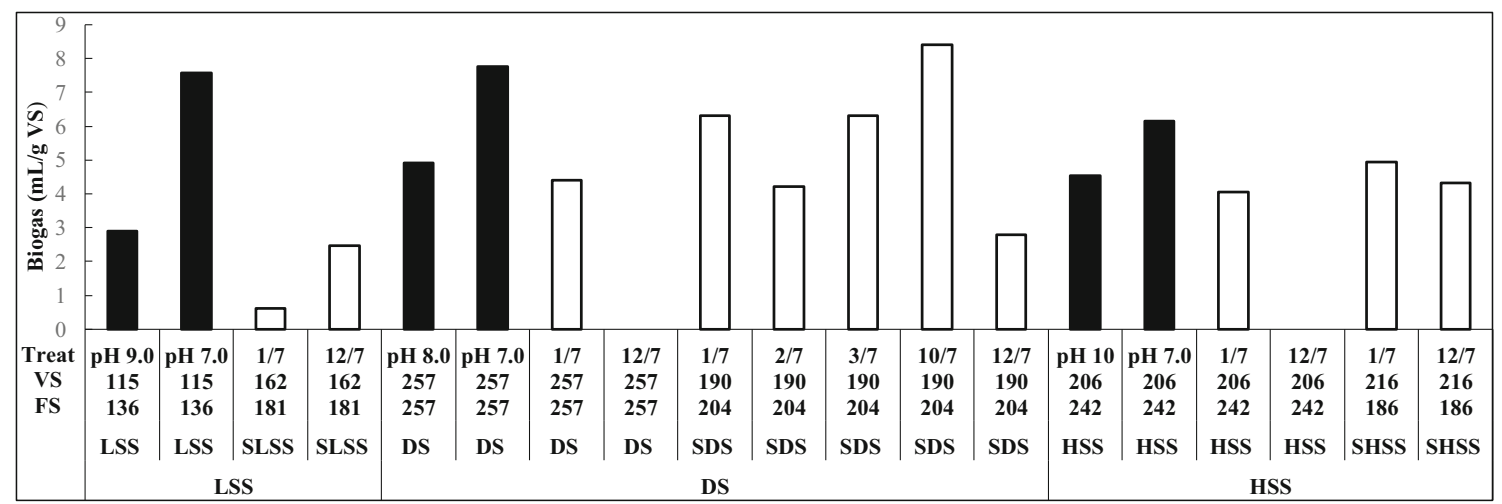

Fig. 2 Treatments (Treat), and volatile (VS) and fixed (FS) solid contents $(\mathrm{g} / \mathrm{kg}$ dry wt) in experiment 1 (E1). Black bars: Biogas production in LSS $(\mathrm{pH} 9.0, \mathrm{pH} 7.0)$, and in LSS amended with DS (pH 8.0, $\mathrm{pH}$ 7.0) or HSS ( $\mathrm{pH} 10.0, \mathrm{pH} 7.0)$; the first value without $\mathrm{pH}$ adjustment, and the second with $\mathrm{pH} 7.0$ adjustment. White bars: Biogas production in LSS amended

with acid-treated (treatment $\mathrm{pH} /$ biogas production $\mathrm{pH}$ : $\mathrm{pH}$ 1/7, 2/7, and 3/7) or alkali (pH 10/7, 12/7) SLSS, DS, SDS HSS, or SHSS, followed by neutralization For all treatments, the average of standard deviations was $0.61 \mathrm{~mL} / \mathrm{g}$ VS $(n=3)$ 

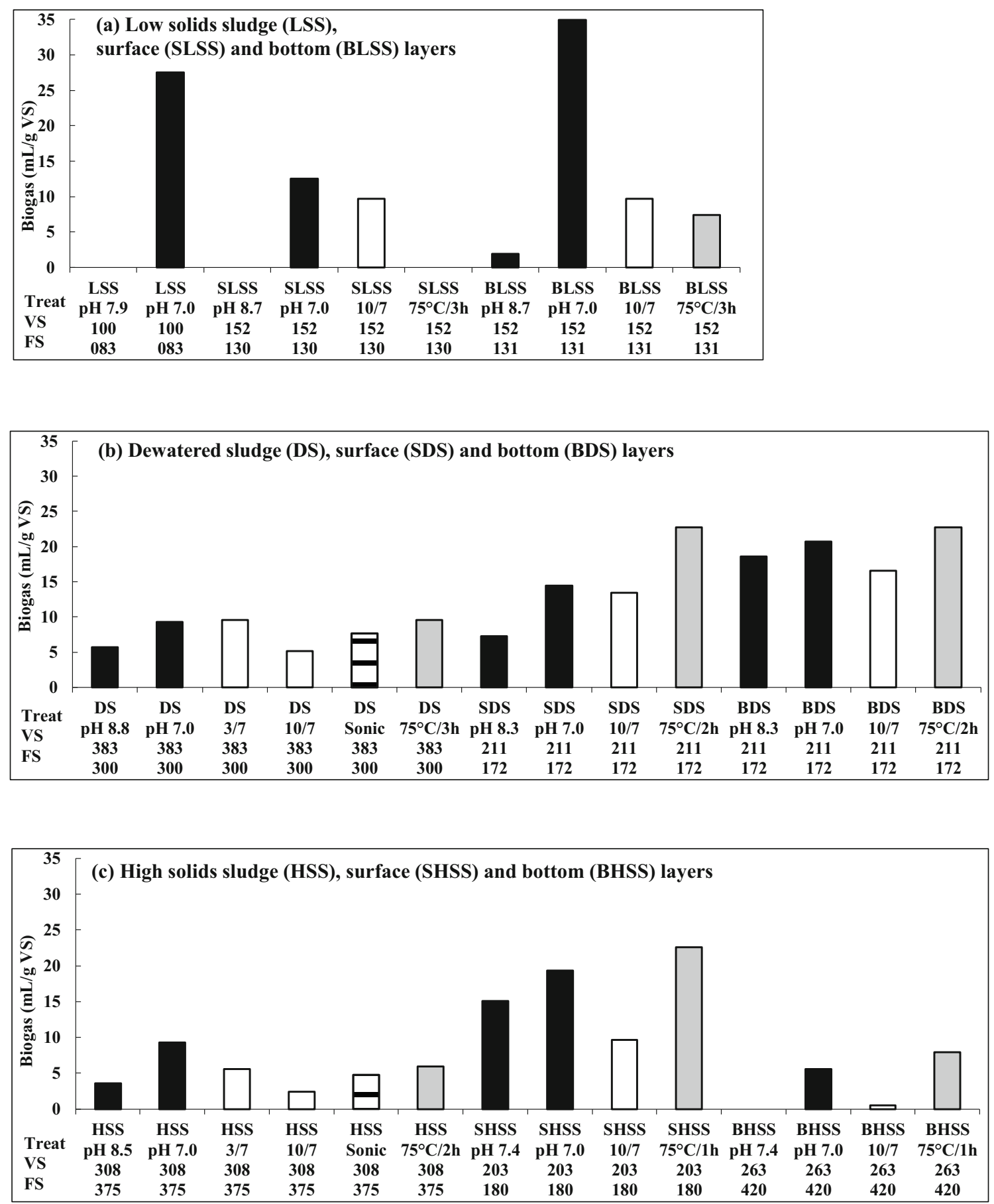

Fig. 3 E2, treatments (Treat, $n=3$ ), and volatile (VS) and fixed (FS) solid contents (g/kg dry wt). a Black bars: Biogas production in LSS ( $\mathrm{pH} 7.9$, $\mathrm{pH} 7.0$ ), and in LSS amended with SLSS (pH 8.7; pH 7.0) or BLSS (pH 8.7, pH 7.0) without and with $\mathrm{pH} 7.0$ adjustment. White bars: Biogas production in LSS amended with alkali-treated (treatment $\mathrm{pH} /$ biogas production pH: $\mathrm{pH}$ 10/7) SLSS or BLSS, followed by neutralization. Gray bars: Biogas production in LSS amended with temperature-treated $\left(75^{\circ} \mathrm{C} / 3 \mathrm{~h}\right)$ SLSS or BLSS. b Black bars: Biogas production in LSS amended with DS (pH 8.8, $\mathrm{pH} 7.0$ ), SDS (pH 8.3, $\mathrm{pH} 7.0$ ), or BDS $(\mathrm{pH} 8.3, \mathrm{pH} 7.0)$ without and with $\mathrm{pH}$ adjustment. White bars: Biogas production in LSS amended with acid-treated (3/7) or alkali-treated (10/7) DS, SDS, or BDS, followed by neutralization. Gray bars: Biogas production in LSS amended with temperature-treated DS $\left(75^{\circ} \mathrm{C} / 3 \mathrm{~h}\right)$, SDS, or BDS $\left(75^{\circ} \mathrm{C} / 2 \mathrm{~h}\right)$. Horizontal line bars: Biogas production in LSS amended with sonicated DS. $\mathbf{c}$ Black bars: Biogas production in LSS amended with HSS (pH 8.5, $\mathrm{pH} 7.0$ ), SHSS (pH 7.4; $\mathrm{pH} 7.0$ ), or BHSS (pH 7.4, $\mathrm{pH} 7.0$ ) without and with $\mathrm{pH}$ adjustment. White bars: Biogas production in LSS amended with acid-treated (3/7) or alkalitreated (10/7) HSS, SHSS, or BHSS, followed by neutralization. Gray bars: Biogas production in LSS amended with temperature-treated HSS $\left(75^{\circ} \mathrm{C} / 2 \mathrm{~h}\right)$, SHSS, or BHSS $\left(75^{\circ} \mathrm{C} / 1 \mathrm{~h}\right)$. Horizontal line bars: Biogas production in LSS amended with the sonicated HSS. For all treatments, the average of standard deviations was $3.3 \mathrm{~mL} / \mathrm{g} \mathrm{VS}(n=3)$ 
wt). Thus, under saturated conditions, biogas production at HSS seemed to continue and ammonia was released further, which was reflected in the increase in $\mathrm{pH}$ and the removal of some of the ammonia by evaporation. Altogether, under aerobic conditions at about $21{ }^{\circ} \mathrm{C}$, ammonia in the digested sludge seemed to be incorporated to biomass and $\mathrm{pH}$ decreased to 7.0 in a few days, but under saturated conditions, the ammonia will remain in solution or evaporate slightly so that the $\mathrm{pH}$ will not decrease. To remove ammonia from the system, for instance, stripping of ammonia is required (Bonmatí and Flotats 2003).

\section{Digested sludge acid, alkali, thermal, and sonolytic treatments}

In E1, the sludges were treated with acid ( $\mathrm{pH} 1.0,2.0$, or 3.0) or alkaline $(\mathrm{pH} 10.0$, or 12.0) and then recycled to biogas production at $\mathrm{pH} 7.0$ (Fig. 2, white bars). According to the results, the biogas yields after the $\mathrm{pH} 1.0$ and 12.0 treatments of the recycled sludges were lower than after the $\mathrm{pH} 7.0$ adjustments (MW, $p<0.001$ ). The biogas yields were the best after the $\mathrm{pH} 1.0,3.0$, and 10.0 treatments of the recycled sludges $(p \leq 0.050)$, the $\mathrm{pH} 10.0$ treatment being the best (MW, $p=0.050$ ), as also reported in Chen et al. (2007), Zhang et al. (2010), and Feki et al. (2015). The ability of pH 3.0 and 10.0-treated recycled sludges to improve biogas production was further investigated in E2 (Fig. 3, white bars). The results showed that the recycling of $\mathrm{pH} 3.0$ and 10.0-treated sludges improved the biogas yield less than the $\mathrm{pH} 7.0$ adjustment alone (MW, $p \leq 0.021$ ).

Digested sludge VS heat and sonolytic hydrolyses were also studied in E2. The recycled slurry was heated at $75^{\circ} \mathrm{C}$ or sonicated until the $\mathrm{pH}$ fell to 7.0 due to ammonia evaporation (Fig. 3, gray bars). According to the results, the heat treatment of the recycled sludges improved the biogas yield as much as the $\mathrm{pH} 7.0$ adjustment (MW, $p=0.304$ ), in

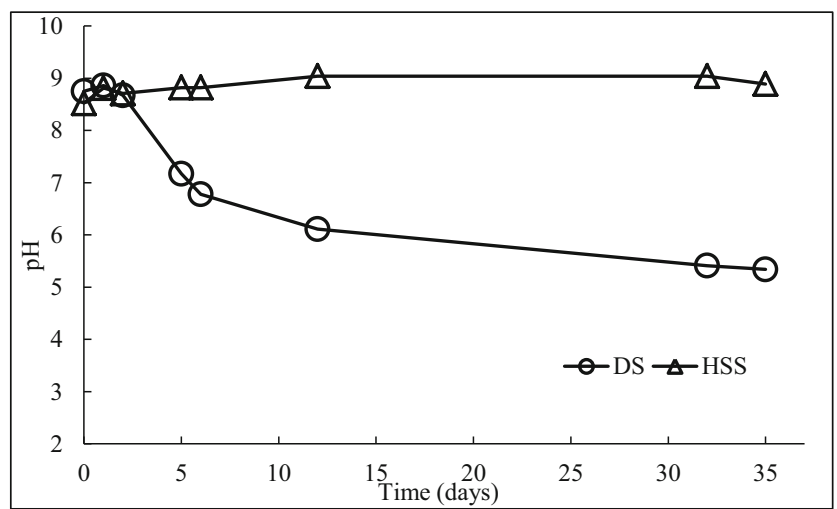

Fig. 4 The changes in the $\mathrm{pH}$ of dewatered (DS) and high solid (HSS) sludges during the incubation at the temperature of $21 \pm 2{ }^{\circ} \mathrm{C}$ for 35 days (the average of standard deviations, $0.05 ; n=3$ ) agreement with other studies stating that thermal treatment is one of the most effective pre-treatments (Bougrier et al. 2006; Hao et al. 2016; Kim et al. 2003; Pérez-Elvira et al. 2006). Thus, the ammonia recovery by heat stripping would at the same time digest the VS more susceptible to microbial use and recyclable back to biogas production (Bonmatí and Flotats 2003). The biogas yields after $1-2-\mathrm{h}$ heating of the recycled sludges were among the highest (Fig. 3b, c, gray bars), while 3-h heating appeared to have adverse effects on biogas production (Fig. 3a, gray bars). The biogas yields from sonicated and recycled DS and HSS did not differ from the yields after heat treatment of the sludges (MW, $p=0.108$ ), but sonication was less efficient treatment than $\mathrm{pH} 7.0$ adjustment (MW, $p=$ 0.003) (Fig. 3b, c, horizontal line bars).

\section{Digested sludge materials}

The sludges recycled for biogas production were LSS, DS, and HSS and their surface and bottom layers. In E1, biogas yields from the recycled LSS, DS, and HSS did not differ (MW, $p \geq 0.453$; Fig. 2). The compositions of the sludges were quite similar, the FS content ranging from 136 to $257 \mathrm{~g} / \mathrm{kg}$ dry wt and the VS content ranging between 115 and $216 \mathrm{~g} / \mathrm{kg}$ dry wt. In E2, by contrast, biogas yield from recycled DS (FS, $300 \mathrm{~g} / \mathrm{kg}$ dry wt) was higher than from recycled HSS (FS, $375 \mathrm{~g} / \mathrm{kg}$ dry wt; MW, $p=0.002$ ), while that from LSS (FS, $83 \mathrm{~g} / \mathrm{kg}$ dry wt) did not differ significantly from DS and HSS, due to large difference in biogas production between untreated (no biogas produced) and $\mathrm{pH}$ 7.0-adjusted LSS (MW, $p=1.000$; Fig. 3, black bars of LSS, DS, and HSS). VS content was highest in DS ( $383 \mathrm{~g} / \mathrm{kg}$ dry wt), moderate in HSS (308 g/kg dry wt), and lowest in LSS (100 g/g dry wt), and still, the biogas yield was highest in $\mathrm{pH}$-adjusted LSS. VS adsorb the elements (Wong et al. 2002); i.e., the highest VS content of DS may have reduced the inhibitory effects of the elements by adsorbing and, at the same time, the highest VS and total C contents of DS supported biogas production (Fig. 3b; Table 2).

The biogas yields from the LSS and DS bottom layers were higher than from the surface layers (MW, $p \leq 0.044$ ), although the VS contents were slightly higher than the FS contents in all layers (Fig. 3a, b). The anaerobic biogas-producing microbial community apparently has grown in the bottom layers during layer separation, while complex organic material may have risen to the surface where aerobic microorganisms also grow. Thus, the most easily accessible substrates for biogas production may have been at the bottom. Interestingly, the biogas production from DS surface and bottom layers was higher than from the original DS (MW, $p \leq 0.006$ ), even though the layer materials were incubated for 28-33 days during surface and bottom separation by post-produced biogas. During the layer separation, some of the substances may disappear in the form of evaporated gases and some may dissolve and 
disappear with the added water, though generally, the elements were concentrated in the surface and bottom layers (Table 2). FS contents in biogas production from recycled SDS and BDS were lower than in DS experiments, although the FS percentages in DS (56.1\%) and SDS/BDS (55.1\%) were nearly the same (Fig. 3b). Dilution of FS and VS could increase biogas production in SDS/BDS compared with DS; ammonia dilution has also been found to increase biogas production (Chen et al. 2008).

In contrast to the LSS and DS, biogas production from the recycled surface layer of HSS was better than from the bottom layer, or from HSS (MW, $p<0.001$ ), but the biogas production between recycled HSS and BHSS did not differ significantly (MW, $p=0.106$; Fig. $3 \mathrm{c}$ ). These differences were most likely due to the highest FS contents in HSS ( $375 \mathrm{~g} / \mathrm{kg}$ dry wt) and BHSS (420 g/kg dry wt), while it was only $180 \mathrm{~g} / \mathrm{kg}$ dry $w t$ in SHSS. When the separation of surface and bottom layers increases the VS concentration on the surface, the biogas production from the surface VS can also be improved due to the decrease in FS.

Biogas production from digested sludges was generally low, and in some experiments, a reliable separation of methane and carbon dioxide would not have been possible due to the small volume; i.e., statistical analyses would not have been possible to do for methane volumes. Furthermore, the number of triplicate samples (required for statistical analyses) was 57 in E1, and 114 in E2, and performing a similar series of experiments on a larger scale would have been challenging. Biogas yields were low because easily available nutrients of the digested sludges had already been used for biogas production; E1 sludges had been shortly aerated; and all sludges were frozen prior to experiments due to the waiting time to separate layers, and even surface and bottom layers were frozen to ensure the same freeze-thaw treatments for all samples. For these reasons, methane was not separated from the biogas in this study. However, it is important to recall that all sludges were from full-scale biogas production and had the microbial community needed for anaerobic digestion. The proportion of methane in biogas was 56-58\% at the BP, and slightly higher $60 \%$ at the WWTP, the LSS sludge of which was used as a microbial inoculum in this study. E3 showed that under saturated conditions, the bacteria in the sludge did not begin to consume ammonia and carbon for aerobic growth with increasing $\mathrm{CO}_{2}$ release, but apparently continued to produce biogas; the phenomenon was even utilized in separating surface and bottom layers. Moreover, despite the low volumes of biogas, many of the differences between the treatments were in good agreement with previous results in the literature, as discussed above. Although the volumes of produced biogas differed between $\mathrm{E} 1$ and $\mathrm{E} 2$, the differences between the same treatments were the same in the two experiments and supported the results of each other. In the following, the results are summarized based on E2.

\section{Summary of treatments}

To evaluate the significance of the results, the biogas yields after the recycled sludge treatments in E2 were plotted as a function of FS (Fig. 5). The biogas yields after the best treatments (KW-MW, $p<0.050$ ), that is after $\mathrm{pH} 7.0$ adjustment and heating at $75^{\circ} \mathrm{C}$ for $1-2 \mathrm{~h}$, decreased exponentially with increasing amounts of FS according to the equation $y=$ $51.46 \mathrm{e}^{-5.05 x}\left(R^{2}=0.921\right)$. The biogas yields after the other recycled sludge treatments were below this curve that is the FS content of the sludges did not limit the biogas production. Thus, heating for $3 \mathrm{~h}$ at $75^{\circ} \mathrm{C}$ apparently had adverse effects on VS composition compared with heating for $1-2 \mathrm{~h}$. For example, volatile fatty acids are formed increasingly in sludge under alkaline conditions (Chen et al. 2007), and they may have been evaporated during prolonged treatment, resulting in reduced biogas production. Sonication for $1 \mathrm{~h}$ may have had similar effects on VS, in agreement with the results in Segura et al. (2016). The inorganic ions added in the $\mathrm{pH} 3.0(\mathrm{HCl})$ and $10.0(\mathrm{KOH})$ treatments and neutralization increased the FS content of digested sludges, thereby enhancing the inhibition of biogas production by FS more than a simple $\mathrm{pH}$ adjustment. The inhibitory effect of increasing FS content appeared to be the major factor limiting biogas production.

Element additions ( $\mathrm{Fe}, \mathrm{Ni}, \mathrm{Co}$ ) have reduced biogas production from food waste with $90.8 \%$ of VS, and it has been explained to be due to the co-precipitation of trace elements essential for biogas production (Yazdanpanah et al. 2018). However, when $\mathrm{Fe}$ has been amended to the digestion of wastewater activated sludge, biogas production has been explained to be improved due to increased sludge VS oxidation (zero-valent iron and activated carbon; photo-Fenton pretreatment; $\mathrm{K}_{2} \mathrm{FeO}_{4}$ ) (Heng et al. 2017; Wang et al. 2017). Combining these previous results with the results of this study, it can be estimated that, in addition to oxidizing the slurry VS,

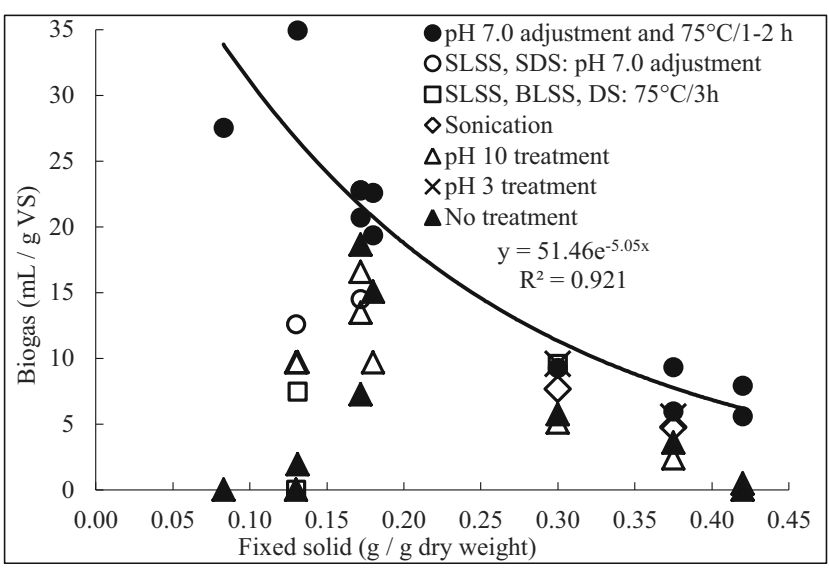

Fig. 5 Biogas yields in different treatments of E2 as a function of the fixed solid content (the average of standard deviations, $3.3 \mathrm{~mL} / \mathrm{g}$ $\mathrm{VS} ; n=3$ ) 
iron may have been involved in precipitating the FS, thereby reducing their inhibitory effects on biogas production, and resulting in improved VS digestion and biogas production. The FS content in wastewater sludge typically is higher than in food waste, about 33-38\% (Feki et al. 2015; Heng et al. 2017; Liu et al. 2018). When the elements are added as part of the sludge pre-treatment prior to anaerobic digestion, the biogas-producing bacterial community may also have become adapted to higher elemental concentrations than the bacterial community of the untreated sludge, such as in anaerobic digestion of rice straw (Xin et al. 2019). Such a change in microbial community structure may enhance sludge VS anaerobic digestion. Nevertheless, the inhibitory effects of increasing FS content during digestion may be the most important factor that ultimately limits biogas production.

In general, microbiological hydrolysis or solubilization of complex carbon compounds like lignocellulose (cellulose, hemicellulose, lignin) has been considered as a rate-limiting step in anaerobic digestion (Chandra et al. 2012; Weiland 2010; Chiu and Lo 2016). However, in this study, biogas production was the highest in the recycled BLSS with the low FS content of $131 \mathrm{~g} / \mathrm{kg}$ dry wt, although BLSS had already lost some of the readily available carbon in the separation of the surface and bottom layers of LSS by the biogas post-production for 33 days (Fig. 3). Correspondingly, the biogas yield from the heat-treated $\left(75^{\circ} \mathrm{C}, 2 \mathrm{~h}\right)$ and recycled SDS was higher than that from the recycled DS, which had a higher FS content ( $300 \mathrm{~g} / \mathrm{kg}$ dry wt) than the SDS (172 g/kg dry wt) that had already undergone the separation of the surface and bottom layers with the loss of biogas. The digested sludge most likely contains microorganisms that degrade compounds like lignocellulose (Chandra et al. 2012; Goswami et al. 2016; Weiland 2010). The inhibitory effect of FS appeared to restrict biogas production from digested and recycled sludge more than the availability of carbon nutrients.

The percentage of VS did not fall below $38.5-56.1 \%$ at the end of biogas production (Figs. 2 and 3), which is in agreement with the earlier results (e.g., Zhang et al. 2008; Grübel and Suschka 2015; Liu et al. 2018). According to European Union legislation, the VS content in landfill must be less than 10\% (European Council 1999), which prevents the digestate from being dumped in a landfill. The digested sludge can contain harmful compounds and drugs that inhibit the agricultural use of the sludge. The FS and water concentrations in the digested sludge were too high for profitable energy production, as most of the energy in the VS would be spent on evaporating the water. The inhibitory effects of inorganic ions should be circumvented, to further convert sludge VS into biogas. One possible method of concentrating 51.6-61.8\% of VS on the surface is flotation, which could be further improved by adjusting the parameters.

\section{Conclusions}

To improve digested sludge VS consumption, the VS of LSS, DS, and HSS were separated to surface and bottom layers using flotation by post-produced biogas, followed by adjusting the $\mathrm{pH}$ of the sludges to the optimum $\mathrm{pH} 7.0$ for biogas-producing microbes; VS digestion with acid, alkali, heat, or sonolytic treatment; and finally biogas production measurements from recycled sludges. The biogas yield was best after the sole $\mathrm{pH} 7.0$ adjustment, and after ammonia evaporation and VS digestion by heat treatment at $75^{\circ} \mathrm{C}$ until the $\mathrm{pH}$ dropped to 7.0 (1-2 h), sonolytic treatment being almost as effective. Acid $(\mathrm{HCl})$ and alkali $(\mathrm{KOH})$ treatments were less effective in improving biogas production from the recycled digestates, as elevated FS levels appeared to limit biogas production more than difficult-to-digest VS.

To improve sludge VS digestion down to the European landfill limit of $10 \%$, methods to concentrate VS and reduce FS should be found. In addition to FS dilution to avoid inhibitory effects, one possible method could be to separate VS into the surface and bottom layers by flotation using biogas postproduction; 51.6-61.8\% VS concentration was achieved in the surface layer using the non-optimized system. As VS and FS concentrations and compositions differ in surface and bottom layers, further optimization of conditions could improve VS utilization from both layers. When the sludge was stored for 35 days under aerobic conditions at $21 \pm 2{ }^{\circ} \mathrm{C}$, the $\mathrm{pH}$ fell most likely due to the use of ammonia as a substrate for microbial growth, whereas under saturated conditions, biogas production appeared to continue with ammonia and biogas evaporating without a decrease in $\mathrm{pH}$. Thus, $\mathrm{pH}$ control and heat treatment to further digest sludge $\mathrm{VS}$ and adjust $\mathrm{pH}$ by removing ammonia (stripping) were the simplest methods for improving biogas production from the recycled sludge, while the biogas postproduction at $21 \pm 2{ }^{\circ} \mathrm{C}$ could be used to separate surface and bottom layers which differ in composition and digestibility.

Acknowledgements Open access funding provided by University of Helsinki including Helsinki University Central Hospital.

Funding information This work was supported by the Employment and Economic Development Office, Lahti, Finland; Regional Innovations and Experimentations (AIKO) funding of Ministry of Economic Affairs and Employment of Finland; and European Regional Development Fund.

Open Access This article is licensed under a Creative Commons Attribution 4.0 International License, which permits use, sharing, adaptation, distribution and reproduction in any medium or format, as long as you give appropriate credit to the original author(s) and the source, provide a link to the Creative Commons licence, and indicate if changes were made. The images or other third party material in this article are included in the article's Creative Commons licence, unless indicated otherwise in a credit line to the material. If material is not included in the article's Creative Commons licence and your intended use is not permitted by statutory regulation or exceeds the permitted use, you will need to obtain permission directly from the copyright holder. To view a copy of this licence, visit http://creativecommons.org/licenses/by/4.0/. 


\section{References}

Adams TM, Sanders JR (1984) The effects of $\mathrm{pH}$ on the release to solution of zinc, copper and nickel from metal-loaded sewage sludges. Environ Pollut B 8:85-99. https://doi.org/10.1016/0143-148X(84) 90020-X

Appels L, Baeyens J, Degrève J, Dewil R (2008) Principles and potential of the anaerobic digestion of waste-activated sludge. Prog Energ Combust 34:755-781. https://doi.org/10.1016/j.pecs.2008.06.002

Apul OG, Sanin FD (2010) Ultrasonic pretreatment and subsequent anaerobic digestion under different operational conditions. Bioresour Technol 101:8984-8992. https://doi.org/10.1016/j.biortech.2010. 06.128

Bååth E (1989) Effects of heavy metals in soil on microbial processes and populations (a review). Water Air Soil Poll 47:335-379. https://doi. org/10.1007/BF00279331

Barber WPF (2016) Thermal hydrolysis for sewage treatment: a critical review. Water Res 104:53-71. https://doi.org/10.1016/j.watres. 2016.07.069

Bonmatí A, Flotats X (2003) Air stripping of ammonia from pig slurry: characterisation and feasibility as a pre- or post-treatment to mesophilic anaerobic digestion. Waste Manag 23:261-272. https:// doi.org/10.1016/S0956-053X(02)00144-7

Bougrier C, Albasi C, Delgenès JP, Carrère H (2006) Effect of ultrasonic, thermal and ozone pre-treatments on waste activated sludge solubilisation and anaerobic biodegradability. Chem Eng Process 45:711-718. https://doi.org/10.1016/j.cep.2006.02.005

Carrère H, Dumas C, Battimelli A, Batstone DJ, Delgenès JP, Steyer JP, Ferrer I (2010) Pretreatment methods to improve sludge anaerobic degradability: a review. J Hazard Mater 183:1-15. https://doi.org/ 10.1016/j.jhazmat.2010.06.129

Chandra R, Takeuchi H, Hasegawa T (2012) Methane production from lignocellulosic agricultural crop wastes: a review in context to second generation of biofuel production. Renew Sust Energ Rev 16: 1462-1476. https://doi.org/10.1016/j.rser.2011.11.035

Chen Y, Jiang S, Yuan H, Zhou Q, Gu G (2007) Hydrolysis and acidification of waste activated sludge at different $\mathrm{pHs}$. Water Res 41:683689. https://doi.org/10.1016/j.watres.2006.07.030

Chen Y, Cheng JJ, Creamer KS (2008) Inhibition of anaerobic digestion process: a review. Bioresouce Technol 99:4044-4064. https://doi. org/10.1016/j.biortech.2007.01.057

Chen JL, Ortiz R, Steele TWJ, Stuckey DC (2014) Toxicants inhibiting anaerobic digestion: a review. Biotechnol Adv 32:1523-1534. https://doi.org/10.1016/j.biotechadv.2014.10.005

Chiu SLH, Lo IMC (2016) Reviewing the anaerobic digestion and codigestion process of food waste from the perspectives on biogas production performance and environmental impacts. Environ Sci Pollut Res 23:24435-24450. https://doi.org/10.1007/s11356-0167159-2

Climent M, Ferrer I, Baeza MM, Artola A, Vázquez F, Font X (2007) Effects of thermal and mechanical pretreatments of secondary sludge on biogas production under thermophilic conditions. Chem Eng J 133:335-342. https://doi.org/10.1016/j.cej.2007.02.020

Córdoba V, Fernández M, Santalla E (2018) The effect of substrate/ inoculum ratio on the kinetics of methane production in swine wastewater anaerobic digestion. Environ Sci Pollut Res 25:21308 21317. https://doi.org/10.1007/s11356-017-0039-6

Devlin DC, Esteves SRR, Dinsdale RM, Guwy AJ (2011) The effect of acid pretreatment on the anaerobic digestion and dewatering of waste activated sludge. Bioresour Technol 102:4076-4082. https:// doi.org/10.1016/j.biortech.2010.12.043

Eswari P, Kavitha S, Kaliappan S, Yeom I-T, Banu JR (2016) Enhancement of sludge anaerobic biodegradability by combined microwave $-\mathrm{H}_{2} \mathrm{O}_{2}$ pretreatment in acidic conditions. Environ Sci
Pollut Res 23:13467-13479. https://doi.org/10.1007/s11356-0166543-2

European Council (1999) Council directive 1999/31/EC of April 1999 on the landfill of waste. Official Journal of the European Communities L $182 / 1$

Feki E, Khoufi S, Loukil S, Sayadi S (2015) Improvement of anaerobic digenstion of waste-activated sludge by using $\mathrm{H}_{2} \mathrm{O}_{2}$ oxidation, electrolysis, electro-oxidation and thermo-alkaline pretreatments. Environ Sci Pollut Res 22:14717-14726. https://doi.org/10.1007/ s11356-015-4677-2

Gaida D, Wolf C, Bongards M (2017) Feed control of anaerobic digestion processes for renewable energy production: a review. Renew Sust Energ Rev 68:869-875. https://doi.org/10.1016/j.rser.2016.06.096

Giller KE, Witter E, McGrath SP (1998) Toxicity of heavy metals to microorganisms and microbial processes in agricultural soils: a review. Soil Biol Biochem 30:1389-1414. https://doi.org/10.1016/ S0038-0717(97)00270-8

Goswami R, Chattopadhyay P, Shome A, Banerjee SN, Chakraborty AK, Mathew AK, Chaudhury S (2016) An overview of physicochemical mechanisms of biogas production by microbial communities: a step towards sustainable waste management. 3. Biotech. 6:72. https://doi.org/10.1007/s13205-016-0395-9

Grübel K, Suschka J (2015) Hybrid alkali-hydrodynamic disintegration of waste-activated sludge before two-stage anaerobic digestion process. Environ Sci Pollut Res 22:7258-7270. https://doi.org/10.1007/ s11356-014-3705-y

Han G, Shin SG, Cho K, Lee J, Kim W, Hwang S (2019) Temporal variation in bacterial and methanogenic communities of three fullscale anaerobic digesters treating swine wastewater. Environ Sci Pollut Res 26:1217-1226. https://doi.org/10.1007/s11356-0171103-y

Hao X, Hu Y, Cao D (2016) Destroying lignocellulosic matters for enhancing methane production from excess sludge. Environ Technol 37:623-629. https://doi.org/10.1080/09593330.2015.1075600

Heng GC, Isa MH, Lim J-W, Ho Y-C, Zinatizadeh AAL (2017) Enhancement of anaerobic digestibility of waste activated sludge using photo-Fenton pretreatment. Environ Sci Pollut Res 24: 27113-27124. https://doi.org/10.1007/s11356-017-0287-5

Kerminen K, Le Moël R, Harju V, Kontro MH (2018) Influence of organic matter, nutrients, and cyclodextrin on microbial and chemical herbicide and degradate dissipation in subsurface sediment slurries. Sci Total Environ 618:1449-1458. https://doi.org/10.1016/j. scitotenv.2017.09.302

Kim J, Park C, Kim T, Lee M, Kim S, Kim SW, Lee J (2003) Effects of various pretreatments for enhanced anaerobic digestion with waste activated sludge. J Biosci Bioeng 95:271-275. https://doi.org/10. 1016/S1389-1723(03)80028-2

Kurola JM, Arnold M, Kontro MH, Talves M, Romantschuk M (2011) Wood ash for application in municipal biowaste composting. Biorsource Technol 102:5214-5220. https://doi.org/10.1016/j. biortech.2011.01.092

Lay J, Li Y, Noike T (1997) Influences of $\mathrm{pH}$ and moisture content on the methane production in high-solids sludge digestion. Water Res 31: 1518-1524. https://doi.org/10.1016/S0043-1354(96)00413-7

Liu S, Yang G, Fu J, Zhang G (2018) Synchronously enhancing biogas production, sludge reduction, biogas desulfurization, and digestate treatment in sludge anaerobic digenstion by adding $\mathrm{K}_{2} \mathrm{FeO}_{4}$. Environ Sci Pollut Res 25:35154-35163. https://doi.org/10.1007/ s11356-018-3438-4

Nguyen D, Gadhamshetty V, Nitayavardhana S, Khanal SK (2015) Automatic process control in anaerobic digestion technology: a critical review. Bioresour Technol 193:513-522. https://doi.org/10. 1016/j.biortech.2015.06.080

Pérez-Elvira SI, Nieto Diez P, Fdz-Polanco F (2006) Sludge minimisation technologies. Rev Environ Sci Bio 5:375-398. https://doi.org/10. 1007/s11157-005-5728-9 
Rafique R, Poulsen TG, Nizami A, Asam Z, Murphy JD, Kiely G (2010) Effect of thermal, chemical and thermo-chemical pre-treatments to enhance methane production. Energy 35:4556-4561. e4561. https:// doi.org/10.1016/j.energy.2010.07.011

Rubio J, Souza ML, Smith RW (2002) Overview of flotation as a wastewater treatment technique. Miner Eng 15:139-155. https://doi.org/ 10.1016/S0892-6875(01)00216-3

Segura Y, Puyol D, Ballesteros L, Martínez F, Melero JA (2016) Wastewater sludges pretreated by different oxidation systems at mild conditions to promote the biofas formation in anaerobic processes. Environ Sci Pollut Res 23:24393-24401. https://doi.org/10.1007/ s11356-016-7535-y

SFS-EN ISO 17294-1 (2004) Water quality. Application of inductively coupled plasma mass spectrometry (ICP-MS). Part 1: general guidelines. Finnish Standards Association, SFS, Helsinki

SFS-EN ISO 17294-2 (2016) Water quality. Application of inductively coupled plasma mass spectrometry (ICP-MS). Part 2: determination of selected elements including uranium isotopes. Finnish Standards Association, SFS, Helsinki

Talja KM, Kaukonen S, Kilpi-Koski J, Malin I, Kairesalo T, Romantschuk M, Tuominen J, Kontro MH (2008) Atrazine and terbutryn degradation in deposits from groundwater environment within the boreal region in Lahti, Finland. J Agric Food Chem 56: 11962-11968. https://doi.org/10.1021/jf802528a

Tyagi VK, Lo S (2011) Application of physico-chemical pretreatment methods to enhance the sludge disintegration and subsequent anaerobic digestion: an up to date review. Rev Environ Sci Bio 10:215242. https://doi.org/10.1007/s11157-011-9244-9

Wang T, Qin Y, Cao Y, Han B, Ren J (2017) Simultaneous addition of zero-valent iron and activated carbon on enhanced mesophilic anaerobic digestion of waste-activated sludge. Environ Sci Pollut Res 24:22371-22381. https://doi.org/10.1007/s11356-017-9859-7

Weiland P (2010) Biogas production: current state and perspectives. Appl Microbiol Biot 85:849-860. https://doi.org/10.1007/s00253-0092246-7

Wong JWC, Xiang L, Chan LC (2002) pH requirement for the bioleaching of heavy metals from anaerobically digested wastewater sludge. Water Air Soil Pollut 138:25-35. https://doi.org/10.1023/A: 1015503828607
Xin L, Guo Z, Xiao X, Peng C, Zeng P, Feng W, Xu W (2019) Feasibility of anaerobic digestion on the release of bioagas and heavy metals from rice straw pretreated with sodium hydroxide. Environ Sci Pollut Res 26:19434-19444. https://doi.org/10.1007/s11356-01905195-x

Yadvika S, Sreekrishnan TR, Kohli S, Rana V (2004) Enhancement of biogas production from solid substrates using different techniques: a review. Bioresour Technol 95:1-10. https://doi.org/10.1016/j. biortech.2004.02.010

Yazdanpanah A, Ghasimi DSM, Kim MG, Nakhla G, Hafez H, Keleman M (2018) Impact of trace element supplementation on mesophilic anaerobic digestion of food waste using Fe-rich inoculum. Environ Sci Pollut Res 25:29240-29255. https://doi.org/10.1007/s11356018-2832-2

Zeng Z, Zheng P, Zhang M, Ghulam A (2019) Performance and working mechanism of a novel anaerobic self-floatation reactor for treating wastewater with high suspended solids. Environ Sci Pollut Res 26: 26193-26202. https://doi.org/10.1007/s11356-019-05885-6

Zhang Y, Li H (2019) Energy recovery from wastewater treatment plants through sludge anaerobic digestion: effect of low-organic-content sludge. Environ Sci Pollut Res 26:30544-30553. https://doi.org/ 10.1007/s11356-017-0184-y

Zhang P, Zeng G, Zhang G, Li Y, Zhang B, Fan M (2008) Anaerobic codigestion of biosolids and organic fraction of municipal solid waste by sequencing batch process. Fuel Process Technol 89:485-489. https://doi.org/10.1016/j.fuproc.2007.11.013

Zhang D, Chen Y, Zhao Y, Zhu X (2010) New sludge pretreatment method to improve methane production in waste activated sludge digestion. Environ Sci Technol 44:4802-4808. https://doi.org/10.1021/ es1000209

Zhang Q, Hu J, Lee D (2016) Biogas from anaerobic digestion processes: research updates. Renew Energ 98:108-119. https://doi.org/10. 1016/j.renene.2016.02.029

Publisher's note Springer Nature remains neutral with regard to jurisdictional claims in published maps and institutional affiliations. 